\title{
Penerapan Strategi Rotating Trio Exchange Untuk Meningkatkan Sikap Percaya Diri Peserta Didik di Sekolah Dasar
}

\author{
Fajar Fahrur Rozi ${ }^{1}$, Pratik Hari Yuwono², Agung Nugroho³ \\ Universitas Muhammadiyah Purwokerto \\ E-mail: Fajarrozi40@gmail.com
}

\begin{abstract}
Abstrak
Penelitian ini bertujuan untuk meningkatkan sikap percaya diripeserta didik pada tema 8 Lingkungan Sahabat Kita melalui strategi Rotating Trio Exchange (RTE). Jenis penelitian ini adalah penelitian tindakan kelas yang terdiri dari dua siklus. Subjek pada penelitian ini adalah Peserta didik kelas V SD Negeri 2 Kebakalan yang berjumlah 24 peserta didik yang terdiri dari 12 peserta didik laki-laki dan 12 peserta didik perempuan. Instrumen penelitian yang digunakan yaitu lembar observasi sikap percaya diri peserta didik dan skala sikap. Hasil penelitian sikap percaya diri peserta didik pada siklus I diperoleh rata-rata 3,02, mengalami peningkatan pada siklus II dengan rata-rata 3,5. Peningkatan ini juga didukung dengan hasil observasi sikap percaya diri peserta didik dengan persentase siklus I sebesar $63 \%$ dan meningkat pada siklus II dengan persentase $86 \%$, artinya sikap percaya diri peserta didik sudah sangat baik saat proses pembelajaran. Hasil penelitian ini menunjukkan bahwa penggunaan strategi Rotating Trio Exchange (RTE) dapat meningkatkan sikap percaya diri dan prestasi belajar peserta didik tema 8 Lingkungan Sahabat Kita pada peserta didik kelas V SD Negeri 2 Kebakalan Kecamatan Mandiraja, Banjarnegara.
\end{abstract}

Kata kunci: Strategi Rotating Trio Exchange (RTE), Percaya Diri, Peserta Didik

\section{PENDAHULUAN}

Pendidikan merupakan faktor penting dalam kehidupan manusia karena dengan adanya pendidikan dapat meningkatkan sumber daya manusia. Sesuai dengan UU Nomor 20 Tahun 2003 yang menjelaskan bahwa pendidikan nasional berfungsi mengembangkan kemampuan dan watak serta peradaban bangsa yang bermartabat dalam rangka mencerdaskan kehidupan bangsa, bertujuan untuk berkembangnya potensi peserta didik agar menjadi manusia yang beriman dan bertakwa kepada Tuhan yang Maha Esa, berakhlak mulia, sehat, berilmu, cakap, kreatif, mandiri, dan menjadi warga negara yang demokratis serta tanggung jawab. Pendidikan yang dimulai dari pendidikan dasar yang pada pendidikan dasar digunakan sebagai landasan peserta didik untuk memenuhi kebutuhan pada pendidikan lanjutan.

Kurikulum 2013 merupakan sarana yang digunakan oleh pemerintah untuk melayani pendidik atau guru. Kurikulum 2013 berfungsi sebagai pedoman dalam pelaksanaan kegiatan pendidikan di sekolah bagi pihak-pihak yang terkait. Dengan adanya kurikulum 2013 ini diharapkan tujuan pembelajaran dapat tercapai yang menyangkut aspek yang terdapat pada standar kompetensi lulusan (SKL) yaitu aspek sikap, pengetahuan, dan keterampilan. Salah satu aspek yang penting dalam kurikulum 2013 adalah aspek sikap. Sikap didefinisikan sebagai perasaan yang dimiliki seseorang terhadap dirinya sendiri dan suatu keseluruhan proses psikologi yang menguasai tingkah laku dan penyesuaian diri (Suryabrata, 2005:248). Dalam diri sesorang terdapat banyak sekali sikap antara lain sikap pantang menyerah, percaya diri, ingin tahu, dan lain sebagainya. Salah satu sikap yang akan dibahas dalam penelitian ini adalah sikap rasa percaya diri.

Percaya diri merupakan hal yang harus dimiliki oleh semua orang karena dengan adanya sikap percaya diri seseorang akan mampu mencapai tujuan hidupnya. Sikap percaya diri adalah gagasan tentang diri sendiri yang mencakup keyakinan, pandangan, dan penilaian seseorang terhadap dirinya sendiri (Desmita, 2009:164). Dengan adanya sikap percaya diri pada diri seseorang maka seseorangg akan mampu menyesuaikan diri dengan lingkungan sekitarnya.

Berdasarkan hasil observasi yang telah peneliti lakukan di kelas V SD Negeri 2 Kebakalan diketahui bahwa sikap percaya diri peserta didik masih rendah, hal ini dibuktikan dengan adanya 
temuan-temuan saat observasi yang berkaitan dengan indikator-indikator sikap percaya diri yaitu pantang menyerah, berani menyatakan pendapat, berani bertanya, mengutamakan usaha sendiri daripada bantuan dari teman, dan berpenampilan tenang.

Berdasarkan hasil observasi yang telah dilakukan diketahui bahwa indikator pantang menyerah dan mengutamakan usaha sendiri daripada bantuan belum tergambar pada diri peserta didik kelas $\mathrm{V}$ SD Negeri 2 Kebakalan. Hal ini dibuktikan dengan sikap peserta didik ketika mengerjakan soal evaluasi yang diberikab oleh guru diketahui bahwa peserta didik lebih memilih jalan yang mudah dalam mengerjakan soal evaluasi yaitu dengan mencotek pekerjaan teman disampingnya. Hal ini membuktikan peserta didik cepat menyerah dalam mengerjakan sesuatu karena tidak ada usaha yang lebih dalam mengerjakan soal evaluasi.

Indikator sikap percaya diri yang lain yaitu berani menyatakan pendapat, berani bertanya, dan berpenampilan tenang juga belum tergambar pada diri peserta didik. hal ini dibuktikan dengan masih banyak peserta didik yang belum memiliki keyakinan terhadap kemampuan dirinya ketika menjawab pertanyaan yang disampaikan oleh guru, peserta didik masih saling tunjuk-menunjuk untuk menjawab pertanyaan. Selain itu, ketika proses pembelajaran berlangsung masih terdapat peserta didik yang bermain sendiri serta juga masih terdapat peserta didik yang duduk didekat jendela menengok ke luar jendela. Ketika proses pembelajaran selesai peserta didik enggan bertanya kepada guru mengenai materi pembelajaran yang telah disampaikan apakah sudah dimengerti atau belum.

Berdasarkan pemaparan di atas peneliti merumuskan upaya yang dapat dilakukan untuk mengatasi sikap percaya diri peserta didik yang masih rendah yaitu dengan mengadakan pembelajaran yang aktif. Karena dengan adanya pembelajaran aktif peserta didik ikut serta atau masuk dalam proses pembelajaran tidak sekedar mendengarkan. Dengan peserta didik yang masuk ke dalam proses pembelajaran maka sikap percaya diri peserta didik dapat meningkat dan mudah untuk diketahui.

Pembelajaran aktif yang digunakan adalah dengan menggunakan strategi Rotating Trio Exchange (RTE), pembelajaran menggunakan strategi ini peserta didik dituntut untuk aktif dan konsentrasi dalam pembelajaran, karena dalam pembelajaran ini terdapat langkah-langkah yang cukup banyak sehingga peserta didik dituntut untuk konsentrasi. Menurut Oktaviany (2017) strategi Rotating Trio Exchange (RTE) merupakan strategi berbasis permainan yang dapat meningkatkan keaktifan serta menciptakan interaksi positif antar peserta didik yang berbeda.

\section{METODE/EKSPERIMEN}

Penelitian ini merupakan Penelitian Tindakan Kelas (PTK). Penelitian ini dilaksanakan selama dua siklus, setiap siklus terdiri dari dua pertemuan. Menurut Arikunto, dkk (2015:2) penelitian tindakan kelas merupakan jenis penelitian yang memaparkan baik proses maupun hasil, yang melakukan PTK di kelasnya untuk meningkatkan kualitas pembelajaran. Penelitian ini terdiri dari empat tahap menurut Kemmis dan Mc. Taggart dalam Trianto (2009:30) yaitu perencanaan (planning), pelaksanaan tindakan (acting), observasi (observing), dan refleksi (reflecting). Pengumpulan data diperoleh melalui beberapa teknik yang umumnya teknik yang digunakan adalah teknik non tes, yang berupa lembar observasi sikap percaya diri dan skala sikap pecaya diri peserta didik. Subjek penelitian tindakan kelas ini adalah seluruh Peserta didik kelas V SD Negeri 2 Kebakalan Kecamatan Mandiraja Kabupaten Banjarnegara dengan jumlah 24 peserta didik, yang terdiri dari 12 peserta didik laki-laki dan 12 peserta didik perempuan.

\section{HASIL DAN PEMBAHASAN}

Sikap percaya diri peserta didik siklus I dan II didapatkan dengan menggunakan lembar skala sikap dan lembar observasi sikap percaya diri peserta didik. lembar skala sikap percaya diri peserta didik diisi sendiri oleh masing-masing peserta didik karena lembar skala sikap merupakan gambaran nyata sikap percaya diri peserta didik. Hasil skala sikap percaya diri peserta didik pada siklus I dan II dapat dilihat pada tabel berikut berikut ini: 
Tabel 1. Hasil Skala Sikap Percaya Diri Peserta Didik

\begin{tabular}{|c|c|c|c|c|}
\hline No & Siklus & Jumalh & Rata-rata & Kriteria \\
\hline 1 & Siklus I & 725 & 3,02 & Baik \\
\hline 2 & Siklus II & 835 & 3,5 & Sangat Baik \\
\hline
\end{tabular}

Berdasarkan tabel 1. Diketahui bahwa pada siklus I sikap percaya diri peserta didik masih rendah karena rata-rata sikap percaya diri peserta didik mendapatkan 3,02 dengan kriteria baik. Namun pada siklus II sikap percaya diri mengalami peningkatan karena mendapatka rata-rata yang cukup tinggi yaitu 3,5 dengan kriteria sangat baik. Dengan hasil tersebut sikap percaya diri siklus I dan siklus II meningkat sebesar 0,48.



Gambar 1. Histogram Skala Sikap

Pengumpulan data sikap percaya diri peserta didik selain menggunakan skala sikap juga menggunakan lembar observasi yang dilakukan pada saat proses pembelajaran berlangsung. Lembar observasi ini diisi oleh observer dengan berpedoman ada kisi-kisi lembar observasi sikap percaya diri. Hasilnya sebagai berikut:

4.2 Hasil Lembar Observasi Sikap Percaya Diri

\begin{tabular}{|c|c|c|c|}
\hline No & Siklus & Persentasi & Kriteria \\
\hline 1 & Siklus I & $63 \%$ & Baik \\
\hline 2 & Siklus II & $86 \%$ & Sangat Baik \\
\hline
\end{tabular}

Berdasarkan tabel 2. di atas diketahui bahwa sikap percaya diri peserta didik yang diketahui melalui lembar observasi sikap percaya diri peserta didik mengalami peningkatan pada siklus I dengan persentase $63 \%$ dengan kriteria baik, dan mengalami peningkatan pada siklus II menjadi $86 \%$ dengan kriteria sangat baik. Dengan hasil tersebut terjadi peningkatan sikap percaya diri peserta didik kelas V SD Negeri 2 Kebakalan sebesar 23\%. Peningkatan pada lembar observasi sikap percaya diri peserta didik kelas V SD Negeri 2 Kebakaln dapat dilihat pada histogram berikut ini 


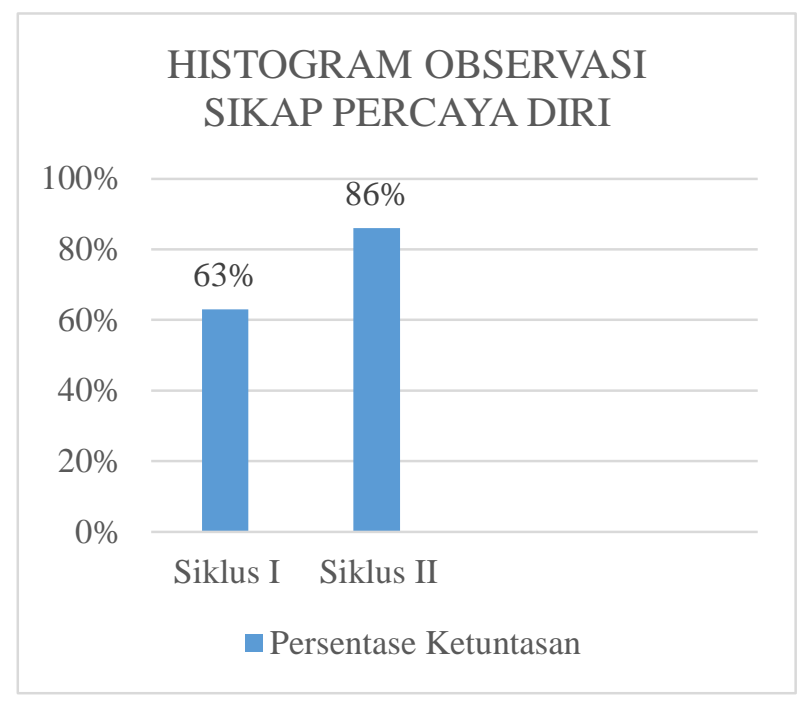

Gambar 2. Histogram Observasi Sikap Percaya Diri

Hasil skala sikap dan lembar observasi sikap percaya diri peserta didik inilah yang digunakan peneliti untuk menentukan apakah penelitian tindakan kelas ini dikatakan berhasil. Berdasarkan hasil skala sikap dan lembar observasi sikap percaya diri peserta didik diketahui bahwa pada siklus I sikap percaya diri peserta didik masih belum mendapatkan nilai yang memuaskan. Hal ini dibuktikan dengan temuan-temuan berupa sikap peserta didik masih bermain sendiri ketika proses pembelajaran berlangsung hal ini membuktikan bahwa indikator sikap percaya diri yang dikemukakan oleh Mulyasa (2013:147) yaitu berpenampilan tenang belum dimiliki oleh peserta didik kelas V SD Negeri 2 Kebakalan. Selain itu ketika proses pembelajaran berlangsung peserta didik masih saling tunjuk menunjuk ketika guru meminta salah satu peserta didik untuk mengerjakan pertanyaan yang diberikan oleh guru dan ketika proses pembelajaran selesai peserta didik masih malu-malu dan tidak mempunyai keberanian untuk bertanya mengenai materi yang belum dipahami. Dengan temuan tersebut membuktikan bahwa indikator sikap percaya diri yang dikemukakan oleh Mulyasa (2013:147) yaitu berani menyatakan pendapat dan berani bertanya belum dimiliki oleh peserta didik.

Indikator sikap percaya diri yang lain yang belum tergambar pada diri peserta didik adalah pantang menyerah dan mengutamakan usaha sendiri dari pada bantuan. Hal ini dibuktikan ketika peserta didik megerjakan soal evaluasi atau mengerjakan tugas, peserta didik lebih memilih untuk melihat hasil pekerjaan teman serta peserta didik akan merasa bosan ketika soal yang dikerjakan dirasa sulit.

Siklus II merupakan perbaikan dari siklus I, pada siklus II dilakukan perbaikan dari proses pembelajaran serta sikap guru. Maksudnya adalah proses pembelajaran dilakukan dengan baik lagi, sikap guru ketika terdapat peserta didik yang bermain sendiri harus selalu diperhatikan dan guru harus dapat memancing agar peserta didik mempunyai keyakinan untuk berpendapat dan bertanya ketika materi pembelajaran belum dimengerti.

Hasil pada siklus II diketahui bahwa sikap percaya diri peserta didik sudah sangat baik, hal ini dibuktikan dengan hasil skala sikap dan lembar observasi yang masing-masing mendapatkan yang sangat baik. Pada siklus II indikator-indikator sikap percaya diri yang dikemukan oleh Mulyasa (2013:147) sudah tergambar pada diri peserta didik. dibuktikan ketika proses pembelajaran sebagian besar peserta didik akif dalam pembelajaran, peserta didik terlihat konsentrasi dan mampu mengikuti proses pembelajaran dengan baik. Peserta didik lebih berani untuk menyatakan pendapatnya ketika diskusi kelompok. Ketika mengerjakan soal evaluasi peserta didik tidak melihat pekerjaan teman serta mempunyai keyakinan terhadap kemampuan dirinya sendiri. Hal ini membuktikan bahwa indikator-indikator sikap percaya diri sudah tergambar pada diri peserta didik kelas V SD Negeri 2 Kebakalan.

Berdasarkan uraian di atas maka dapat disimpulkan bahwa strategi rotating trio exchange 
dapat meningkatkan sikap percaya diri peserta didik pada sekolah dasar. sejalan dengan kesimpulan tersebut kelebihan dari strategi Rotating Trio Exchange (RTE) menurut Yuliyati (2016) adalah peserta didik dapat mengaktualisasikan diri sehingga peserta didik memiliki keyakinan atas kemampuan dirinya sendiri.

Temuan-temuan pada siklus I yang berhubungan pada sikap percaya diri peserta didik adalah diketahui bahwa sikap percaya diri peserta didik masih rendah hal ini dibuktikan dari adanya indikator sikap percaya diri yang dikemukakan oleh Mulyasa (2013:147) belum mendapatkan hasil yang memuaskan. Indikator yang dapat dikatakan belum mendapatkan hasil yang memuaskan adalah indikator berani bertanya. Pada siklus I saat proses pembelajaran berlangsung ataupun ketika proses pembelajaran sudah selesai belum banyak peserta didik yang bertanya kepada guru apakah materi yang disampaikan sudah dipahami atau belum.

Selain indikator berani bertanya terdapat indikator berani mengutarakan pendapat yang belum mendapatkan hasil yang memuaskan. Saat proses pembelajaran berlangsung ketika kegiatan diskusi masih banyak peserta didik yang bermain dengan temannya, saat kegiatan diskusi hanya ketua kelompok yang mengerjakan lembar kerja peserta didik. terlebih lagi ketika kegiatan presentasi hasil diskusi kelompok, hanya beberapa siswa yang berani membacakan hasil diskusinya. Peserta didik yang lain saling tunjuk untuk membacakan hasil diskusi kelompok.

Hal ini dikarenakan pada siklus I guru belum sepenuhnya menggunakan cara untuk mengajak peserta didik agar mau bertanya mengenai materi pembelajaran serta guru belum melaksanakan pengecekan atau bimbingan ketika peserta didik melaksanakan kegiatan diskusi kelompok, dalam kegiatan presentasi kelompok yang seharusnya seluruh anggota kelompok maju untuk membacakan hasil diskusi kelompok namun guru meminta hanya perwakilan kelompok yang membacakan hasil diskusi kelompok. Selain itu antusias peserta didik terhadap guru ketika menjelaskan materi pembelajaran masih kurang peserta didik lebih memilih bermain dengan temannya.

Maka dari itu diperlukan adanya perubahan yang harus dilakukan pada siklus II agar sikap percaya diri peserta didik dapat mencapai indikator ketuntasan. Langkah-langkah yang harus dilakukan pada siklus II agar sikap percaya diri peserta didik. Siklus II ini merupakan bentuk perbaikan yang dilakukan agar sikap percaya diri peserta didik dapat menjadi lebik. Pada siklus II ini guru lebih teliti ketika peserta didik sedang melaksanakan diskusi kelompok guru lebih sering berjalan mengamati kegiatan diskusi kelompok, pada siklus II ini kegiatan presentasi kelompok yang pada siklus I dilakukan oleh perwakilan kelompok pada siklus II ini kegiatan presentasi kelompok dilakukan oleh seluruh anggota kelompok. Guru sudah mampu dalam membangun kecakapan bertanya peserta didik ketika materi pembelajaran belum dimengerti. Sehingga dengan dilakukannya perbaikan pada siklus II maka rata-rata serta persentase sikap percaya diri peserta didik dapat meningkat mencapai indikator ketuntasan.

Indikator-indikator sikap percaya diri yang dikemukakan oleh Mulyasa (2013:147) yang dijadikan pedoman untuk menyusun lembar observasi dan skala sikap di atas merupakan ciri-ciri seseorang mempunyai sikap percaya diri. Maka dari itu dibutuhkan hasil yang baik dari tiap tiap indikator sikap percaya diri agar dapat dikatakan sikap percaya diri seseorang dapat dikatakan baik. Sikap percaya diri peserta didik dapat dibentuk atau ditingkat melalui proses pembelajaran yang aktif dan menyenangkan. Ketika proses pembelajaran dapat berajalan dengan aktif serta melibatkan aktivitas peserta didik maka tidak menutup kemungkinan sikap percaya diri peserta didik dapat terbentuk.

Proses pembelajaran yang aktif dan menyenangkan merupakan pembelajaran yang melibatkan peserta didiknya dalam proses pembelajaran, dalam proses pembelajaran tidak hanya proses mentransfer ilmu namun pembelajaran yang terjadi di dalam kelas haruslah memberikan peluang kepada peserta didik untuk aktif. Artinya adalah di dalam proses pembelajaran guru harus mampu melibatkan peserta didik untuk mampu menciptakan suasana belajar yang menyenangkan sehingga peserta didik aktif bertanya, mempertanyakan dan mengemukakan gagasan dan memberikan kesempatan pada peserta didik untuk bertanyan ataupun mengemukakan pendapatnya. Sejalan 
dengan pendapat yang dikemukakan oleh Bonwell dan Eison dalam Novianingsih (2016:6) salah satu karakteristik pembelajaran aktif adalah adanya kelas pembelajaran yang bukan sekedar mendengarkan.

Dalam penelitian ini peneliti dan guru berupaya untuk menciptakan pembelajaran yang aktif dan menyenangkan yang mampu melibatkan peserta didik dalam proses pembelajarannya. Untuk menciptakan itu semua peneliti dan guru menggunakan strategi pembelajaran agar proses pembelajaran dapat berjalan dengan baik. Strategi pembelajaran yang digunakan adalah strategi Rotating Trio Exchange (RTE). Peneliti dan guru memilih strategi ini karena dalam pelaksanaannya strategi ini menuntut peserta didik untuk aktif dalam pembelajaran dan mampu menyesuaikan dengan kelompok-kelompok yang berbeda.

Strategi Rotating Trio Exchange (RTE) merupakan strategi yang dapat meningkatkan keaktifan peserta didik, dengan adanya keaktifan peserta didik dalam proses pembelajaran maka sikap percaya diri peserta didik dalam proses pembelajaran akan menjadi lebih baik. Hal ini sejalan dengan pendapat yang dikemukakan oleh Yuliyati (2016) bahwa salah satu kelebihan dari strategi Rotating Trio Exchange (RTE) adalah peserta didik mampu mengaktualisasikan diri sehingga peserta didik memiliki keyakinan atas kemampuan dirinya sendiri.

Kegiatan pembelajaran menggunakan strategi Rotating Trio Exchange (RTE) memberikan dampak yang sangat besar bagi sikap percaya diri peserta didik dalam pembelajaran, karena pembelajaran menggunakan strategi Rotating Trio Exchange (RTE) membuat peserta didik tidak ada rasa kebosanan dalam pembelajaran. karena dalam pembelajaran ini peserta didik terlibat langsung dalam proses pembelajaran sehingga guru tidak terus-menerus untuk menyampaikan materi dengan metode ceramah. Pelaksanaan pembelajaran dengan strategi ini dilakukan dengan merotasi anggota kelompok setiap satu kali pertanyaan sehingga peserta didik akan lebih aktif dalam proses pembelajaran (Isjoni, 2010:59)

Pelaksanaan pembelajaran menggunakan strategi ini peserta didik akan lebih aktif dalam pembelajaran, sehingga sikap percaya diri peserta didik dapat meningkat karena dengan strategi ini peserta didik lebih serinng terlibat dalam pembelajaran dan akan semakin mudah bagi guru untuk mengetahui sikap percaya diri peserta didik dalam pembelajaran.

\section{PENUTUP}

Simpulan

Berdasarkan hasil penelitian yang telah dipaparkan di atas maka disimpulkan bahwa strategi Rotating Trio Exchange (RTE) dapat meningkatkan sikap percaya diri peserta didik sekolah dasar, hal ini dibuktikan dengan adanya peningkatkan hasil skala sikap siklus I yang mendapat rata-rata 3,02 dan meningkat pada siklu II dengan rata-rata 3,5. Hal ini juga didukung dengan hasil observasi sikap percaya diri peserta didik pada siklus I yang mendapat persentase sebesar $63 \%$ dan meningkat pada siklus II dengan persentase sebesar $86 \%$.

Saran

Guru dapat menggunakan strategi Rotating Trio Exchange (RTE) sebagai alternatif yang dapat digunakan pada pembelajaran yang lain.

Penelitian selanjutnya yang akan menggunakan strategi Rotating Trio Exchange (RTE) diharapkan dapat menggunakannya pada jenjang yang berbeda

Pelaksanaan strategi ini lebih baik peserta didik agar lebih aktif dan konsentrasi.

\section{UCAPAN TERIMAKASIH}

Terimakasih kepada rektor Universitas Muhammadiyah Purwokerto, Dosen Pembimbing, Dosen PGSD Universitas Muhammadiyah Purwokerto, Kepala SD Negeri 2 Kebakalan beserta jajarannya, Kedua orang tua saya dan adik-adik saya. 
DAFTAR PUSTAKA

Arikunto, S, dkk. 2015. Penelitian Tindakan Kelas. Jakarta: Bumi Aksara

Depdiknas. 2003. Undang-Undang Nomor 20 Tahun 2003, Tentang Sistem Pendidikan Nasional. Jakarta. Departemen Pendidikan Nasional

Desmita. 2009. Psikologi Perkembangan Peserta Didik. Bandung: PT Remaja Rosdakarya Isjoni. 2010. Cooperative Learning. Bandung: Alfabeta

Mulyasa, E. 2013. Pengembangan dan Implementasi Kurikulum 2013. Bandung: PT Remaja Rosdakarya

Novianingsih. 2016. Pendekatan Pembelajaran Aktif, Kreatif, Efektif, dan Menyenangkan Dalam Pembelajaran Matematika Sekolah Dasar. Jurnal Pendidikan Guru Sekolah Dasar. Vol 2,2

Oktaviany, N. Penerapan Model Pembelajaran Tipa Rotating Trio Exchange (RTE) dengan Menggunakan Media Kartu Arisan pada Kompetensi Dasar Sambungan Kayu Peserta Didik Kelas X Keterampilan Kayu SMK Negeri 2 Surabaya. Jurnal Kajian Pendidikan Teknik Bangunan. vol 2,2 Suryabrata, S. 2006. Psikologi Pendidikan. Jakarta: PT Raja Grafindo

Trianto. 2011. Panduan Lengkap Penelitian Tindakan Kelas. Jakarta: Prestasi Pustakarya

Yuliyati, dkk. 2016. Penerapan Model Pembelajaran Tipe Rotating Trio Exchange (RTE) untuk Meningkatkan Hasil Belajar Peserta Didik pada Mata Pelajaran Fisika. Jurnal Pendidikan Fisika. Vol 4,2 